\title{
Homologue distribution patterns of 2,3,7,8-chloro-substituted PCDD/F in Bavarian soils
}

\author{
Raimund Prinz ${ }^{*}$ (D)
}

\begin{abstract}
Background: Soil-background values of PCDD/F concentrations are usually conveniently displayed as toxic equivalent (TEq), being a bulk parameter of all relevant 7 PCDD- and 10 PCDF-congeneres, chloro-subsidized at the 2nd, 3rd, 7th and 8th carbon atom. Data here are ample, not so survey on congenere/homologue patterns occurring in soils. The sufficient number of samples taken within this analysis allowed first a well-grounded evaluation.

Results: OCDD proved to be the dominant congenere in all samples (forest and agriculture), however, in considerably different concentrations. As expected, highest level was detected in forest organic layers, followed by forest top soils, cropland- and grassland top soils. Although highest in concentration, OCDD only contributes to $0.17 \%$ (both forest organic- and top soil layer), respectively, $0.4 \%$ (cropland) and $0.3 \%$ (grassland) to TEq. The influence of lower chlorinated homologues on TEq is strongest in forest top soils (72\%) followed by $67 \%$ (forest organic layers), cropland top soil (63\%) and grassland (61\%). Although all homologue patterns (forest and agriculture) give a fairly similar picture, a test of significance $\left(x^{2}\right)$ proved a different population of forest samples.
\end{abstract}

Conclusions: The resemblance of the homologue patterns throughout all utilization suggests that agent levels are explained mainly by diffuse atmospheric depositions rather than by specific land use input.

Keywords: PCDD/F-homologues, Soil samples, Forest organic layers, Top soil layers, Ubiquitous emission

\section{Introduction}

Polychlorinated dibenzo- $p$-dioxins and dibenzofurans are amongst the most persistent and toxic pollutants known in soils (e.g. [1, 2]. Significant and toxically hazardous are 7 dibenzodioxin- and 10 dibenzofuran-congeners, being subsidized at the 2nd, 3rd, 7th and 8th carbon atom via chlorine. 2,3,7,8-TCDD (2,3,7,8-tetra chloro dibenzodioxin) also known as a major contaminant in Agent Orange (a herbicide used during the Vietnam War) [3] is considered to be the most harmful congener. It is, therefore, provided with factor 1 within calculation of the bulk parameter "Toxic Equivalent" (TEq). All other congeners adding to TEq vary within orders of magnitude (0.1 up to 0.0001) [4] (Fig. 1).

TEq as a bulk parameter, however, does not allow detailed insight onto single congeners or homologues of $\mathrm{PCDD} / \mathrm{F}$ which in return can give valuable information

*Correspondence: Raimund.Prinz@lfu.bayern.de

Bavarian Environment Agency, Hof, Germany on the origin of the PCDD/F emission, as PCDD/F usually is a side-product of organic synthesis and burning organic material. The congener-/homologue contents are, therefore, considered to be fingerprints.

In general, higher chlorinated homologues are more stable and, therefore, longer lasting and persistent in soils [5]. Oxidative biodegradation in soils is executed mainly by microorganisms and some fungi favoring humid, organic and $\mathrm{pH}$-neutral soils. The less chlorine is bound to the benzene rings the more rapid degradation follows. Degradation of higher chlorinated homologues seems to occur favourably under anaerobic conditions. Therefore, the abundance of higher chlorinated homologues outnumbers that of the lower chlorinated homologues. This matches quite well with research done on atmospheric samples carried out by Castro-Jiménez et al. [6].

To get a better picture on the distributive situation of $\mathrm{lcH}$ and hcH in Bavarian forest- and agricultural soils, it 

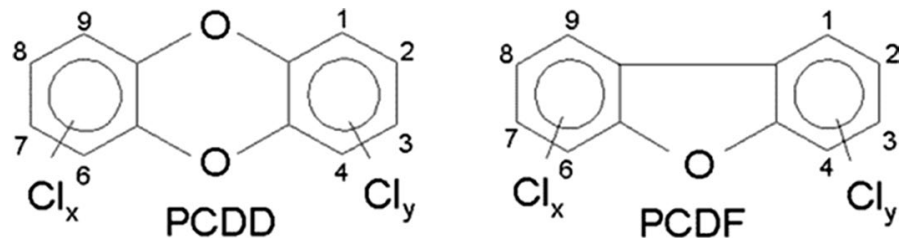

Fig. 1 Structure of PCDD and PCDF (Taken from Frauenhofer IVV)

seemed worthwhile to compare $\mathrm{lcH}$ and hcH via a dimensionless quotient $\left(Q_{\mathrm{H}}\right)$ (cf. Eq. 1).

$$
Q_{\mathrm{H}}=\frac{\sum \mathrm{lcH}}{\sum \mathrm{hcH}} \quad \text { with } Q_{\mathrm{H}}<1
$$

\section{Hypothesis}

The more similar $Q_{\mathrm{H}}$ of forest- and agricultural samples derived from top soil layers are the less anthropogenic influence can be postulated and accordingly the stronger ubiquitous impact appears to be. As hcH is very much more abundant than $\mathrm{lcH}, Q_{\mathrm{H}}$ will always be $<1$.

Besides the comparison between forest- and agricultural top soil samples, it also appeared to be worthwhile taking a closer look at possible differences between crop- and grassland top soil samples. Due to alleged higher anthropogenic impact, cropland samples could presumably be slightly higher in concentration than those deriving from grassland.

\section{Materials and methods}

The $\sum \mathrm{PCDD} / \mathrm{F}$ concentrations are displayed as toxic equivalent [TEq WHO 1998 in Van den Berg et al. [7]] in $\left[\mathrm{ng} \mathrm{kg}^{-1}\right]$ in dry matter (DM) of fine soil and the background values both for $\mathrm{TEq}$ and the homologues are defined as $90 \%$ percentile of the outlier eliminated sample collective. Outliers are considered to be concentrations exceeding the 1.5 interquartile deviations. Values below detection limits are computed as 0.00 (lower bound). Homologue concentrations are not converted to TEq and are shown as detected in $\mathrm{n} \mathrm{kg}^{-1} \mathrm{DM}$.

The following 7 PCDD- and 10 PCDF-congeners-all chloro-subsidized at the 2nd, 3rd, 7th and 8th carbon atom-were analysed:

\begin{tabular}{|c|c|}
\hline PCDD & PCDF \\
\hline 2378-TetraCDD & 2378-TetraCDF \\
\hline 12378-PentaCDD & 12378-PentaCDF \\
\hline 123478-HexaCDD & 23478-PentaCDF \\
\hline 123678-HexaCDD & 123478-HexaCDF \\
\hline 123789-HexaCDD & 123678-HexaCDF \\
\hline 1234678-HeptaCDD & 123789-HexaCDF \\
\hline \multirow[t]{4}{*}{ 12346789-OctaCDD } & 234678-HexaCDF \\
\hline & 1234678-HeptaCDF \\
\hline & 1234789-HeptaCDF \\
\hline & 12346789-OctaCDF \\
\hline
\end{tabular}

Lower chlorinated homologues are considered to be the tetra- and penta-chlorinated $\mathrm{PCDD} / \mathrm{F}$, whereas the higher chlorinated homologues comprise the hexa-, hepta- and octa chlorinated PCDD/F.

Samples were all taken only in rural regions to excerpt background values. All samples derive from soil profiles burrowed at least $1 \mathrm{~m}$ in depth. Soil horizons were labelled according to KA4 [8]. Sampling method was executed horizon wise according to LABO [9]. Top soil horizons are hence all horizons up to max. of $30 \mathrm{~cm}$ depth and/or all A-Horizons. Organic layers were separated in the field by soilscientists using a steel framework $20 \times 20 \times 10 \mathrm{~cm}$. Figure 2 displays the sample sites (forest, crop- and grassland). Analysis is executed on dry matter $\left(105^{\circ} \mathrm{C}\right)$ (DIN ISO 11465:12.96 [10]). The mineral compounds were conducted on fine soil $(<2000 \mu \mathrm{m}$ grain size) by application of DIN 19683-2:04.97 [11]. Organic layers were dried and then ground to particle size of $60 \mu \mathrm{m}$ bevor analysed (DIN ISO 11464 [12]).

Detection method Extraction via toluol (20 h, Soxhlet); chromatographic purification via silica gel/sulfuric acid, quantification analysis: GC-HRMS (DIN38414-24:04.98 [13]).

\section{Results}

\section{Homologues}

The examination of homologues within different land use (forest versus agriculture) should show a more or less similar homologue pattern, unless anthropogenic impact has an overwhelming effect upon the samples taken from agricultural sites. Forest samples, especially organic layers, usually show higher concentrations in comparison to agricultural samples as forest sites-foremost coniferous forests-function as a kind of filter (e.g. [14]). And persistant organic pollutants (POPs) are strongly lipophilic and, therefore, predominantly attached to the organic matter.

A comparison between grass- and cropland aims to identify feasible anthropogenic effects. Cropland is usually subject to higher anthropogenic input.

\section{Forest organic layers}

Table 1 displays descriptive statistical results of the organic layers. Homologues of (tetra), (penta), (hexa), 


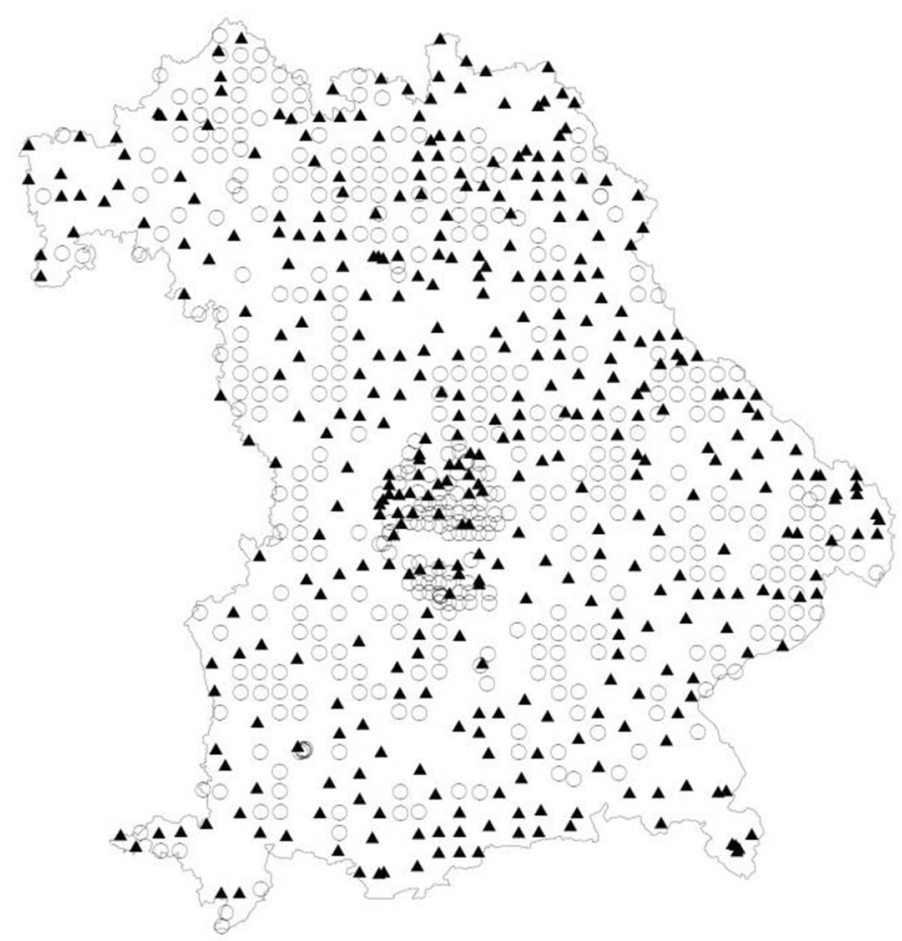

Fig. 2 Sampling sites (circle: agriculture; triangle: forest)

Table 1 Descriptive statistical results of PCDD/F-homologues [ng $\mathbf{~ k g}^{-1} \mathrm{DM}$ ] in organic layers of Bavarian forest soils

\begin{tabular}{llllllllllll}
\hline & TCDD & PeCDD & HxCDD & HpCDD & OCDD & TCDF & PeCDF & HxCDF & HpCDF & OCDF & TEq \\
\hline$n$ & 313 & 315 & 314 & 311 & 314 & 311 & 312 & 312 & 311 & 310 & 312 \\
O $(n)$ & 4 & 2 & 3 & 6 & 3 & 6 & 5 & 5 & 6 & 7 \\
Min & 0.00 & 0.00 & 0.00 & 0.00 & 0.00 & 0.00 & 0.00 & 0.00 & 0.00 & 0.00 & 0.00 \\
Max & 2.3 & 14 & 53 & 200 & 1100 & 46 & 82 & 112 & 191 & 185 & 57 \\
MV & 0.59 & 3.6 & 15 & 61 & 314 & 14 & 21 & 33 & 50 & 44 \\
Med & 0.51 & 3.0 & 13 & 52 & 250 & 13 & 18 & 28 & 41 & 33 \\
90 & 1.2 & 6.8 & 27 & 104 & 580 & 25 & 39 & 61 & 94 & 92 & 33 \\
\hline
\end{tabular}

$O(n)$, number of outliers; MV, mean value; Med, median; $90,90 \%$ percentile

(hepta) and (octa) chlorinated dibenzodioxin (CDD) and dibenzofuran (CDF) are displayed.

The homologue distribution of organic layers is visualized in Fig. 3 using the $90 \%$ percentile.

As Fig. 3 displays, OCDD concentrations clearly outnumber all other homologues. However, multiplied with the WHO-TEq-Factor of 0.0001, OCDD only contributes to $0.17 \%$ of the $90 \%$ percentile of TEq $\left(33.3 \mathrm{ng} \mathrm{kg}^{-1} \mathrm{DM}\right)$. In contrast, $67 \%$ of TEq is generated by the sum of $\mathrm{lcH}$ DD/F-homologues.

The calculated $Q_{\mathrm{H}}$ for organic layers is 0.08 as the percentage of $\mathrm{lcH}$ to $\mathrm{hcH}$ bears a ratio of 7:93.

Within forest sites, Hangen and Prinz (Bayerisches Landesamt für Umwelt [15]) could, however, identify regions with diverging concentrations of $\mathrm{PCDD} / \mathrm{F}$ in organic-as well as in top soil layers (cf. Figs 4 and 5).

Higher concentrations detected in NE-Bavaria are most probably due to brown coal emissions caused by the close by Czech coal-power plants in Sokolov. Those in NW Bavaria are assumed to be caused by the nearby industrial region of Frankfurt [16].

A median comparison of some selected congeners within the subspaces (Sub) 1-4 (cf. Fig. 5) is to be seen in Table 2.

Looking at the data of Table 1 and comparing the median of TEq (15 $\mathrm{ng} \mathrm{kg}{ }^{-1}$ ) for the overall population $(n=312)$ with the median of the subspaces varying from 10.5 to 22.7 , the overall median of $15 \mathrm{ng} \mathrm{kg}^{-1}$ seems to 


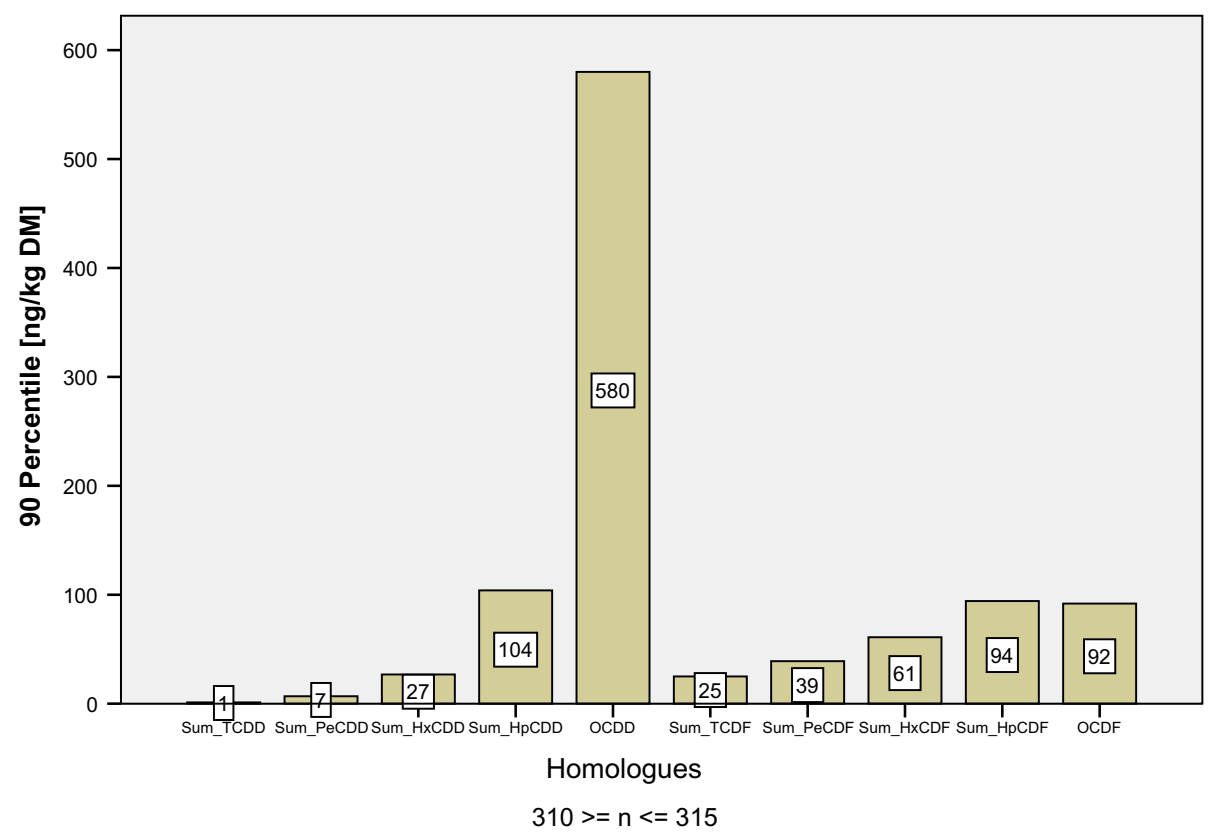

Fig. 3 Homologue pattern of 2,3,7,8-chloro subsidized PCDD/F in organic layers of Bavarian forest soils (outlier eliminated)

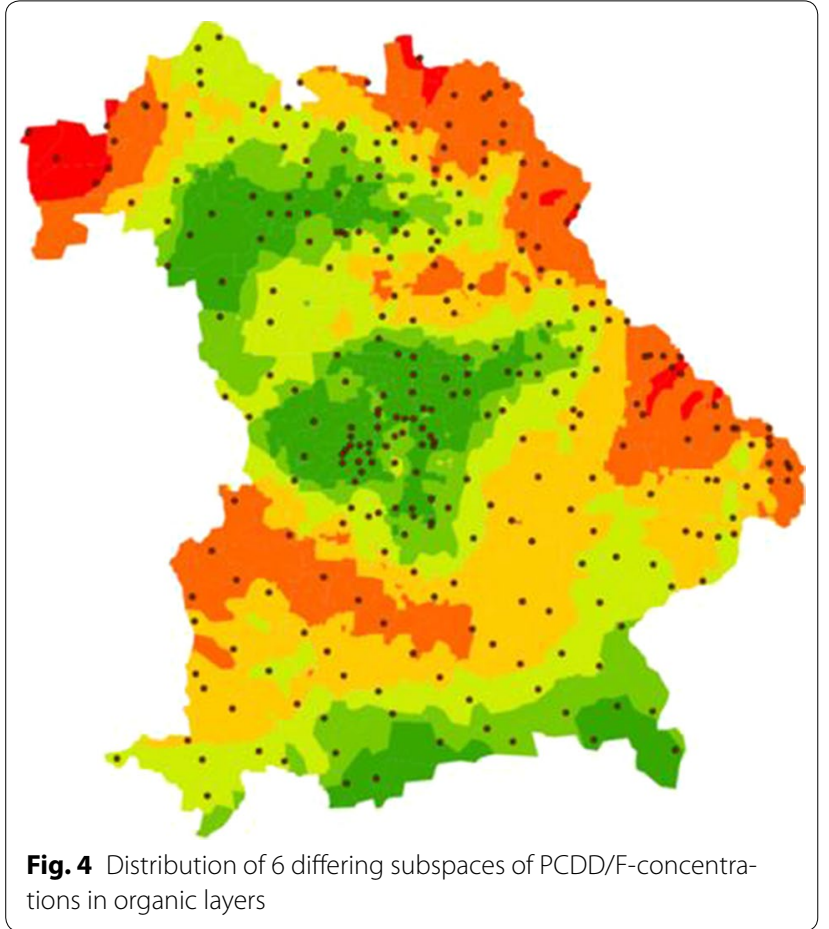

be quite well in the middle implicating a more or less homogenies distribution and hence proposing the applicability of forests representing background values.

\section{Forest top soil layers}

As expected top mineral layers of forest soils show a different picture in quantity. Organic pollutants such as PCDD/F are lipophilic and are, therefore, highly attached to soil organic matter [17] on the one hand; on the other hand, also specific weight in mineral top soils is very much higher. Hence, mass-related values in mineral top soil layers are usually lower in concentration (cf. Table 3 and Fig. 6).

As can be shown in Fig. 6 OCDD values are also dominant in the mineral soil components but by a far lower margin. In contrast to the organic soil layer though, OCDD- and OCDF rates in mineral top soils are very much closer. OCDD values in organic layers are five times higher than those of $\mathrm{OCDF}$, whereas in mineral layers the factor only reaches up to three.

Just as in organic layers OCDD contributes merely 0.17 to the $90 \%$ percentile of TEq $\left(4.8 \mathrm{ng} \mathrm{kg}^{-1} \mathrm{DM}\right)$. $\mathrm{TCDD} / \mathrm{F}$ and PeCDD/F in contrast account for $72 \%$ of TEq.

The calculated $Q_{\mathrm{H}}$ for mineral forest top soil layers is 0.07 as the percentage of $\mathrm{lcH}$ to hcH bears a ratio of 6:94.

\section{Agricultural top soil layers Cropland}

Due to anthropogenic influences, agricultural soils differ not only in their pedogenetic phenotype but also in agent content in comparison to forest soils. On 


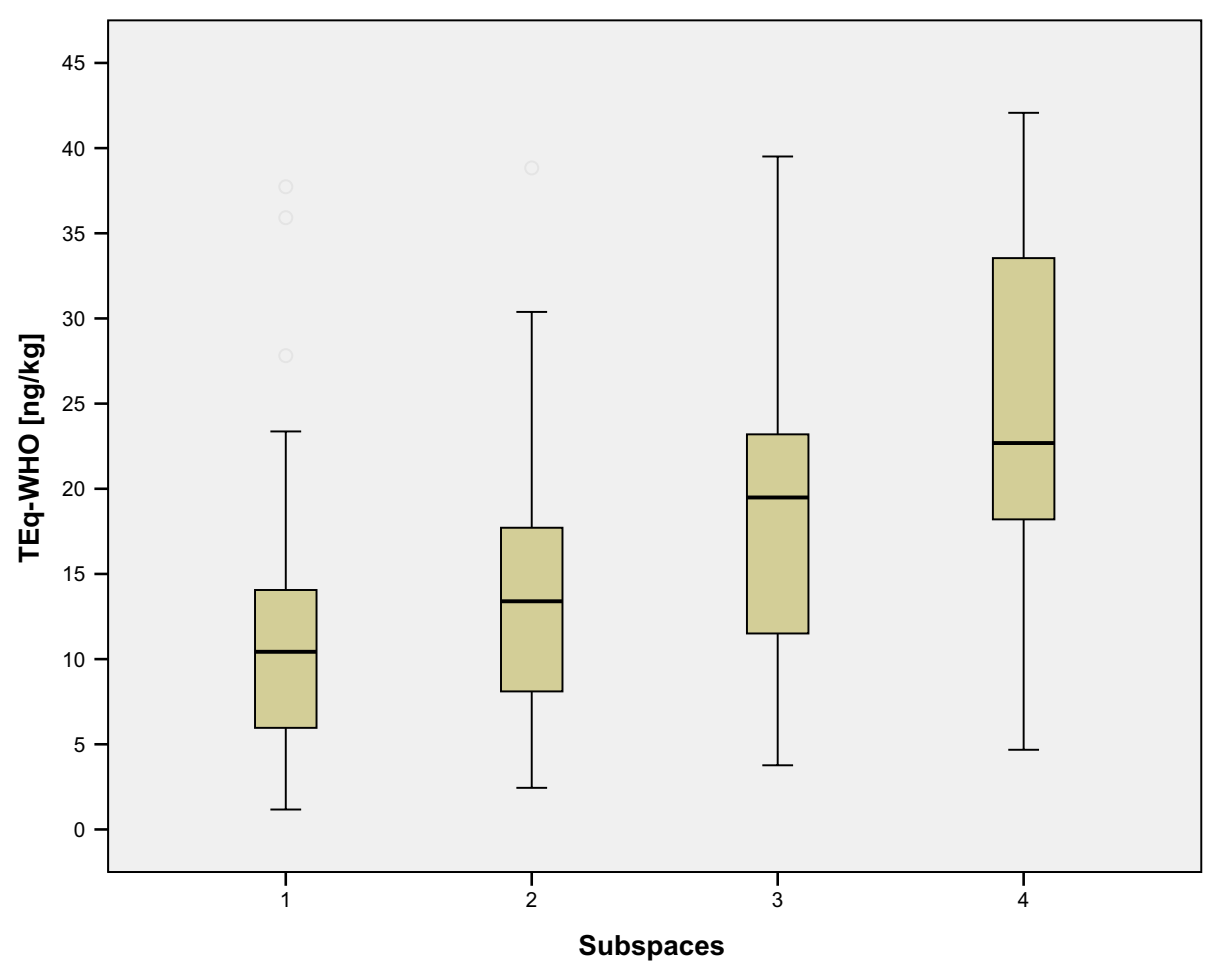

Fig. 5 Box-Whisker plot of the aggregated PCDD/F subspaces

Table 2 Median comparison of selected congeners withinsubspaces

\begin{tabular}{|c|c|c|c|c|}
\hline & $\begin{array}{l}\text { Sub } 1 \\
82 \geq n \leq 89\end{array}$ & $\begin{array}{l}\text { Sub } 2 \\
46 \geq n \leq 47\end{array}$ & $\begin{array}{l}\text { Sub } 3 \\
76 \geq n \leq 78\end{array}$ & $\begin{array}{l}\text { Sub } 4 \\
78 \geq n \leq 79\end{array}$ \\
\hline $2,3,7,8 \mathrm{TCDD}$ & 9.4 & 11.0 & 15.3 & 17.0 \\
\hline $2,3,7,8 \mathrm{TCDF}$ & 0.3 & 0.43 & 0.63 & 0.7 \\
\hline $\begin{array}{c}1,2,3,6,7,8 \\
\mathrm{HxCD}\end{array}$ & 4.4 & 5.9 & 6,5 & 9.6 \\
\hline $\begin{array}{c}1,2,3,6,7,8 \\
\text { HxCF }\end{array}$ & 6.0 & 7.3 & 9.6 & 14.0 \\
\hline OCDD & 160 & 220 & 263 & 370 \\
\hline OCDF & 22.0 & 30.0 & 33.3 & 62 \\
\hline TEq & 10.5 & 12.9 & 19.4 & 22.7 \\
\hline
\end{tabular}

the one hand, permanent crop yield will subduct nutrients as well as pollutants; on the other hand, there is an extra input by adding farm- and mineral fertilisers. Farm fertiliser will boost humus content, which of course is beneficial in many ways. Mineral fertilisers in contrast often contain harmful pollutants such as Uranium or Cadmium. Sewage sludge occasionally even contains traces of endocrine disruptors and other harmful organic substances or their metabolites which finally led to the ban of application of sewage sludge as a fertiliser in Germany within the next 10 years. In 2014, a total of 283,000 tons of

Table 3 Descriptive statistical results of PCDD/F-homologues [ng kg ${ }^{-1}$ DM] in Bavarian forest top soil layers

\begin{tabular}{|c|c|c|c|c|c|c|c|c|c|c|c|}
\hline & TCDD & PeCDD & HxCDD & HpCDD & OCDD & TCDF & PeCDF & $\mathrm{HxCDF}$ & HpCDF & OCDF & TEq \\
\hline$n$ & 399 & 393 & 396 & 391 & 389 & 386 & 392 & 395 & 399 & 398 & 394 \\
\hline$O(n)$ & 10 & 16 & 13 & 18 & 20 & 23 & 17 & 14 & 10 & 11 & 15 \\
\hline Min & 0.00 & 0.00 & 0.00 & 0.53 & 2.50 & 0.00 & 0.00 & 0.00 & 0.00 & 0.00 & 0.04 \\
\hline Max & 0.33 & 1.6 & 7.7 & 29 & 145 & 6.8 & 11 & 21 & 38 & 48 & 8.5 \\
\hline MV & 0.07 & 0.4 & 2.0 & 8.1 & 42 & 1.8 & 3.1 & 5.0 & 10 & 14 & 2.6 \\
\hline Med & 0.05 & 0.3 & 1.6 & 6.1 & 31 & 1.2 & 2.4 & 3.8 & 8.2 & 12 & 2.1 \\
\hline 90 & 0.2 & 0.8 & 3.8 & 16 & 82 & 3.7 & 6.4 & 11 & 19 & 28 & 4.8 \\
\hline
\end{tabular}

$O(n)$, number of outliers; MV, mean value; Med, median; $90,90 \%$ percentile 


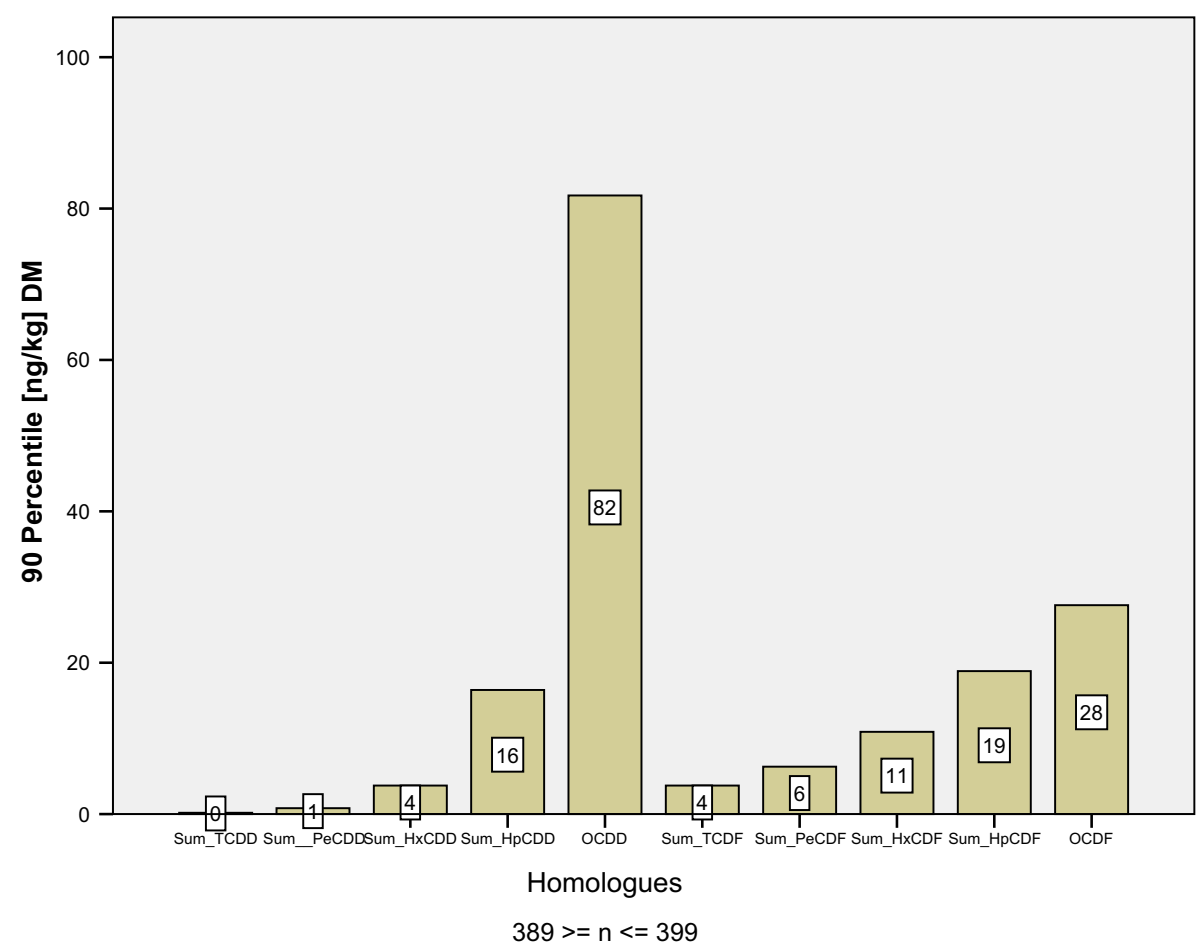

Fig. 6 Homologue pattern of 2,3,7,8-chlorine subsidized PCDD/F in Bavarian forest top soil layers (outlier eliminated)

Table 4 Descriptive statistical results of PCDD/F-homologues [ng $\mathbf{~ g g}^{-1} \mathrm{DM}$ ] in Bavarian cropland top soil layers

\begin{tabular}{|c|c|c|c|c|c|c|c|c|c|c|c|}
\hline & TCDD & PeCDD & $\mathrm{HxCDD}$ & HpCDD & OCDD & TCDF & PeCDF & $\mathrm{HxCDF}$ & $\mathrm{HpCDF}$ & OCDF & TEq \\
\hline$n$ & 217 & 223 & 222 & 221 & 215 & 223 & 221 & 222 & 220 & 218 & 217 \\
\hline$O(n)$ & 17 & 11 & 12 & 13 & 19 & 11 & 13 & 12 & 14 & 16 & 17 \\
\hline Min & 0.00 & 0.00 & 0.00 & 0.00 & 0.00 & 0.00 & 0.00 & 0.00 & 0.00 & 0.00 & 0.00 \\
\hline Max & 0.1 & 0.5 & 2.4 & 13 & 71 & 1.5 & 2.0 & 4.7 & 6.5 & 12 & 1.7 \\
\hline MV & 0.02 & 0.1 & 0.7 & 4.1 & 23 & 0.5 & 0.7 & 1.4 & 2.4 & 3.6 & 0.7 \\
\hline Med & 0.00 & 0.1 & 0.6 & 3.4 & 18 & 0.4 & 0.7 & 1.3 & 2.3 & 3.2 & 0.6 \\
\hline 90 & 0.04 & 0.2 & 1.1 & 6.8 & 43 & 0.7 & 1.2 & 2.1 & 3.5 & 5.8 & 1.0 \\
\hline
\end{tabular}

$O(n)$, number of outliers; MV, mean value; Med, median; $90,90 \%$ percentile

sewage sludge incurred in Bavaria; 22.4\% were deployed on agricultural soils. ${ }^{1}$

Mineral top soil samples from cropland and grassland alike show dominant OCDD concentrations with the highest ratio of influence on TEq by cropland with $0.4 \%$. OCDD concentrations in grassland only account for $0.3 \%$ on total TEq.

The calculated $Q_{H}$ for cropland top soil layers is 0.03 . Tetra- and penta-chlorinated DD and DF account for $63 \%$ of TEq (Table 4 ).

\footnotetext{
${ }^{1}$ https://www.destatis.de/DE/PresseService/Presse/Pressemitteilungen/2015/12/PD15_462_32214.html;jsessionid=0FE11C0F50655FAF6D BB6E7D447C0A45.cae4.
}

\section{Grassland}

Data in Table 5 display a similar homologue pattern to cropland. The abundance of OCDD (factor 5 higher than OCDF) also proves to be characteristical in grassland samples (cf. Fig. 4). The higher chlorinated homologues account for $39 \%$ of $\sum \mathrm{TEq}, Q_{\mathrm{H}}$ with 0.03 is virtually equal to that of cropland, with a ratio of $\mathrm{lcH}$ to $\mathrm{hcH}$ (3:97) in grassland being identical to that of cropland (cf. Table 5).

Table 6 finally displays the homologue quotient andpattern of the lower-and higher chlorinated homologues from forest and agricultural samples. The closest rate between $\mathrm{lcH}$ and $\mathrm{hcH}$ is detected in organic layers followed by forest top soil samples. Agricultural soil samples are within identical range (Fig. 7). The 
Table 5 Descriptive statistical results of PCDD/F-homologues [ng $\mathrm{kg}^{-1} \mathrm{DM}$ ] in Bavarian grassland top soil layers

\begin{tabular}{|c|c|c|c|c|c|c|c|c|c|c|c|}
\hline & TCDD & PeCDD & HxCDD & HpCDD & OCDD & TCDF & PeCDF & $\mathrm{HxCDF}$ & HpCDF & OCDF & TEq \\
\hline$n$ & 215 & 218 & 210 & 206 & 206 & 213 & 207 & 200 & 191 & 201 & 194 \\
\hline$O(n)$ & 12 & 9 & 17 & 21 & 21 & 14 & 20 & 27 & 36 & 26 & 33 \\
\hline Min & 0.00 & 0.00 & 0.00 & 0.82 & 3.0 & 0.08 & 0.00 & 0.20 & 0.40 & 0.29 & 0.12 \\
\hline Max & 0.1 & 0.6 & 2.5 & 13 & 72 & 1.5 & 2.2 & 4.7 & 7.1 & 12 & 1.8 \\
\hline MV & 0.02 & 0.14 & 0.91 & 4.9 & 24 & 0.51 & 0.89 & 1.7 & 2.9 & 4.3 & 0.76 \\
\hline Med & 0.01 & 0.1 & 0.8 & 4.3 & 21 & 0.41 & 0.79 & 1.6 & 2.8 & 3.8 & 0.71 \\
\hline 90 & 0.04 & 0.2 & 1.3 & 7.4 & 38 & 0.7 & 1.4 & 2.6 & 4.8 & 6.9 & 1.2 \\
\hline
\end{tabular}

$O(n)$, number of outliers; MV, mean value; Med, median; $90,90 \%$ percentile

Table 6 Comparison between forest and agricultural samples

\begin{tabular}{|c|c|c|c|c|c|c|c|c|}
\hline & \multicolumn{4}{|c|}{ Forest } & \multicolumn{4}{|c|}{ Agriculture } \\
\hline & \multicolumn{2}{|c|}{ Organic layer } & \multicolumn{2}{|c|}{ Top soil } & \multicolumn{2}{|c|}{ Cropland top soil } & \multicolumn{2}{|c|}{ Grassland top soil } \\
\hline & $\mathrm{IcH}$ & $\mathrm{hcH}$ & $\mathrm{IcH}$ & hcH & $\mathrm{IcH}$ & hcH & IcH & hcH \\
\hline$H_{p}$ & 7 & 93 & 6 & 94 & 3 & 97 & 3 & 97 \\
\hline$H_{p}-T E q$ & 67 & 33 & 72 & 28 & 63 & 37 & 61 & 39 \\
\hline$Q_{H}$ & 0.075 & & 0.068 & & 0.031 & & 0.032 & \\
\hline
\end{tabular}

$Q_{\mathrm{H}^{\prime}}$, homologue quotient of $\mathrm{IcH}$ to $\mathrm{hcH}$ [dimensionless]; $H_{\mathrm{p}^{\prime}}$, homologue pattern of IcH to hcH [\%]; $H_{\mathrm{p}}-\mathrm{TEq}$, homologue pattern of IcH and hcH in terms of TEq [\%]

influence of lcH upon TEq is highest in forest samples, thus, allowing the following sequence: $Q_{\mathrm{H}}$-Organic layer $(0.08)>Q_{\mathrm{H}^{-}}$-Forest top soil $(0.07)>Q_{\mathrm{H}^{-}}$-Grassland top soil $(0.03) \approx Q_{\mathrm{H}^{-}}$Cropland top soil $(0.03)$.

\section{Discussion}

In order to get an idea whether the specific forest-, crop-, and grassland top soil samples derive from identical or diverse populations a test of significance $\chi^{2}$ (Chi square) was executed. Both clusters, the lcH as well as the hcH, were examined with regard to their origin of land use.

As shown in Table $7 \mathrm{lcH}$ - and hcH-data deriving from forest samples prove to be a different population on a probability of $\alpha=0.05$ in comparison to those deriving either from crop- or grassland.

\section{$\mathrm{H}_{1}\left(\mathrm{H}_{0}\right)^{*}$}

Crop- and grassland $\mathrm{lcH}-/ \mathrm{hcH}$-data are to be interpreted with great care, as the $\chi^{2}$ test value of $\chi^{2}=2.706$ for lcH is barely exceeded $\left({ }^{\wedge} X^{2}=2.765\right)$. Difference between the hcH of crop- and grassland data seems to be greater $\left({ }^{\wedge} X^{2}=30.15\right)$ yet is still to be considered faint in comparison to the other combinations which reign within multitudes of hundreds. A Kruskal-Wallis ( $H$ test) verifies these results and conclusions.

The only conclusion which with reasonable certainty can be drawn out of these statistical tests is that forest samples obviously differ quite clearly from samples taken from agricultural sites. If, as presumed, PCDD/F-emission originates from ubiquitous sources then the reason that forest samples differ from agricultural ones can be assumed in the manner forest sites filter atmospheric pollutants and/ or accumulation rates are higher in forest soils due to the lack of dilution via anthropogenic interactions such as, e.g. ploughing. Specific land use practice such as ploughing, harrowing and liming (in agricultural sites) may promote rapid microbiological breakdown of the lower chlorinated dioxins and-furans in comparison to forest top soil contents. Also $\mathrm{pH}$ values and organic carbon contents differ considerably in forest soils in comparison to soils under agricultural sites: examined forest organic layers reveal mean values of $\mathrm{pH} 3.7$, their top soil layers reveal mean values of $\mathrm{pH} 3.6$, while cropland top soils show $\mathrm{pH}$ values of 6.3 and grassland top soils 5.8. Both organic carbon and $\mathrm{pH}$ are significant parameters relating to $\mathrm{PCDD} / \mathrm{F}$ accumulation or breakdown [18]. These facts may also account for the diverse population portrayed in Table 7 .

\section{Data of the German UBA}

Comparison with data of the German Environmental Protection Agency (Umwelt Bundesamt (UBA)) indicates that emission-related homologues from, e.g. dust show considerably different patterns (cf. Fig. 8) and do not match with patters related to soil probes taken from rural areas. Soil background values have their peak at OCCD, whereas dust has peaks at higher chlorinated 

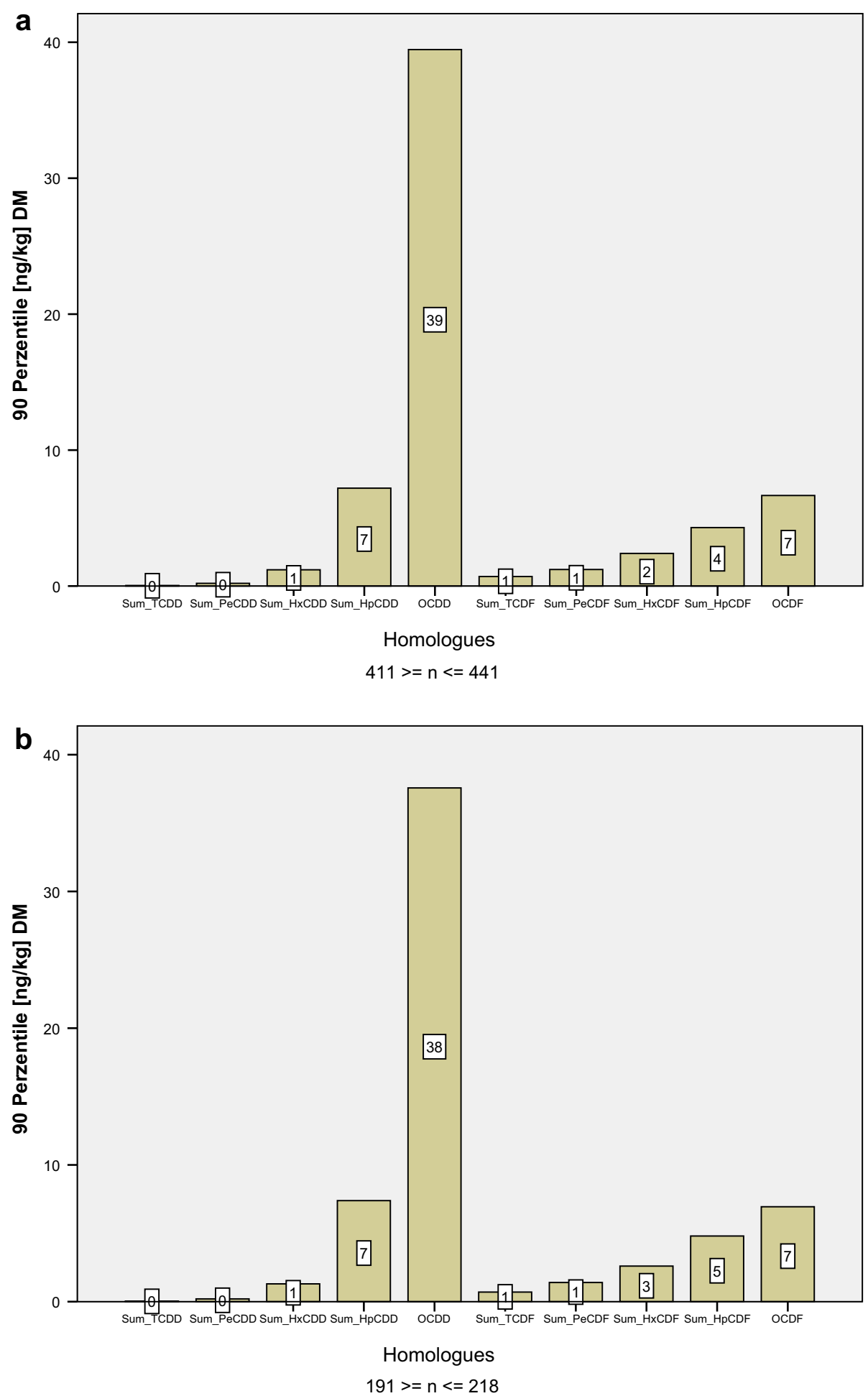

Fig. 7 a Homologue pattern of 2,3,7,8-chlorine subsidized PCDD/F in Bavarian cropland top soil layers (outlier eliminated). b Homologue pattern of 2,3,7,8-chlorine subsidized PCDD/F in Bavarian grassland top soil layers (outlier eliminated) 
Table 7 Test of significance $\left(x^{2}\right)$ of IcH and hcH taken from forest (F)-, crop (C)- and grassland (G) mineral top soil samples

\begin{tabular}{|c|c|c|c|c|c|c|}
\hline & IcH & & & hcH & & \\
\hline & F versus $C$ & F versus $G$ & C versus $\mathrm{G}$ & F versus $C$ & F versus $G$ & $C$ versus $\mathrm{G}$ \\
\hline $\mathrm{H}$ & $\mathrm{H}_{1}$ & $\mathrm{H}_{1}$ & $\mathrm{H}_{1}\left(\mathrm{H}_{0}\right)^{*}$ & $\mathrm{H}_{1}$ & $\mathrm{H}_{1}$ & $\mathrm{H}_{1}\left(\mathrm{H}_{0}\right)^{*}$ \\
\hline
\end{tabular}

$\mathrm{H}$ : Hypothesis $(a=0.05) ; \mathrm{H}_{0}$ : Samples belonging to same population; $\mathrm{H}_{1}$ : Samples deriving from diverse population

${ }^{*}$ cf. text

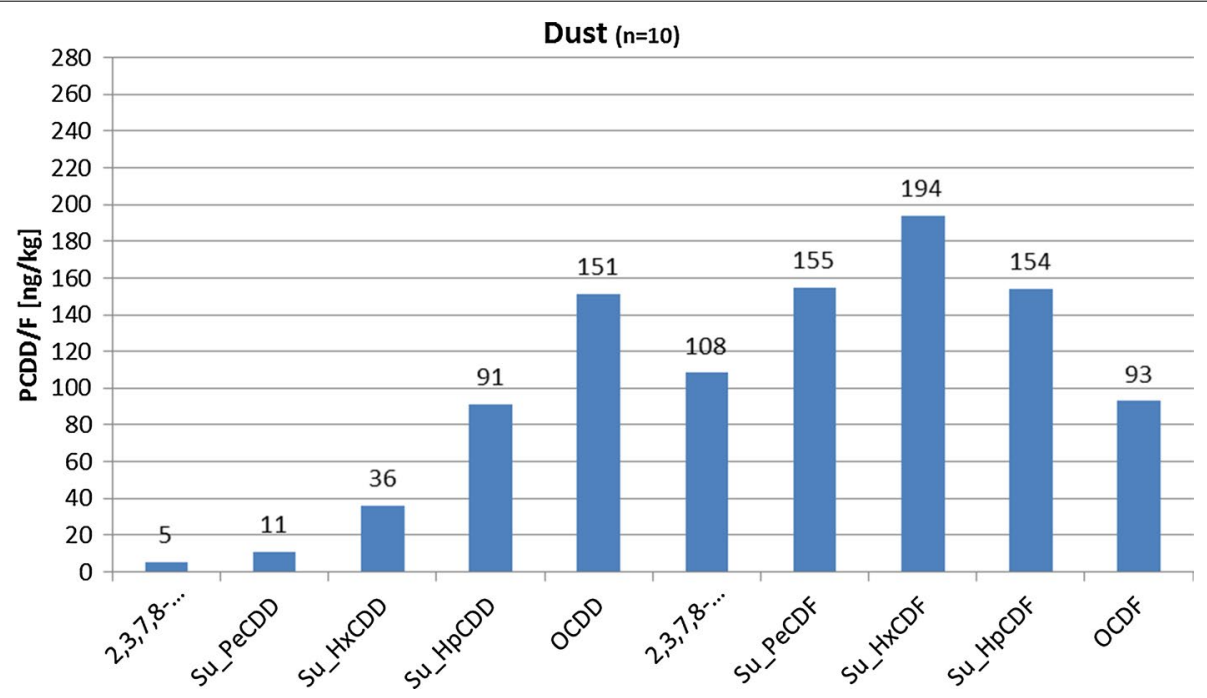

Fig. 8 Homologue pattern of dust (UBA) (Data taken from [19])

PCDF's. Dust emissions therefore do not-as possibly presumed-dominate PCDD/F patterns in rural soils.

Samples deriving from wood, biodiesel, solvents and synthetic material analysed by the UBA also all show no resemblance to the homologue patterns in soils.

$\mathrm{PCDD} / \mathrm{F}$-emissions originating from technical products (cf. Fig. 9) in contrast seem to match quite well with the homologue pattern of soil samples. Both homologue patterns peak at OCDD with raised values at $\mathrm{HxCDD} / \mathrm{F}, \mathrm{HpCDD} / \mathrm{F}$ and OCDF. This seems to indicate that $\mathrm{PCDD} / \mathrm{F}$ values of soil samples deriving from rural areas may nowadays be predominately influenced by emissions originating from technical products.

\section{Conclusions}

1. Data confirm predominance of OCDD in all samples (forest, crop- and grassland).

2. $Q_{H}$ in forest soils is highest, hence concentrations of lower chlorinated homologues are in comparison to agricultural sites also highest and, therefore, influence TEq strongest.

3. TEq under forest use is, therefore, mainly determined by $\mathrm{lcH}(72 \%)$, while crop- and grassland sites are "merely" influenced by $63 \%$ resp. $61 \%$.
4. Samples deriving from forest sites are statistically part of a different population ( $\chi^{2}$ (Chi square) test of significance and $H$ test) because of quantity, the patterns, however, are similar.

5. Calculated $Q_{\mathrm{H}}$ and relation of $\mathrm{lcH}$ to hcH in cropand grassland soils are virtually of one and the same magnitude.

6. Similarity of the homologue patterns of cropland on the one hand and grassland on the other suggests that there seems to be no considerable influence of land use on concentration levels of PCDD/F.

7. The similar homologue patterns of PCDD/F-concentration levels in crop- and grassland suggest that agent levels are explained mainly by diffuse, ubiquitous, atmospheric depositions rather than specific land use parameters.

8. Calculated $H_{\mathrm{P}}$ of agricultural soils may lead to the assumption that specific land use practice such as ploughing, harrowing and liming promotes rapid microbiological breakdown of the lower chlorinated dioxins and furans in comparison to forest top soil contents.

9. Homologue-comparison with data of the German Environmental Protection Agency (UBA) suggests 
Technical products $(n=9)$

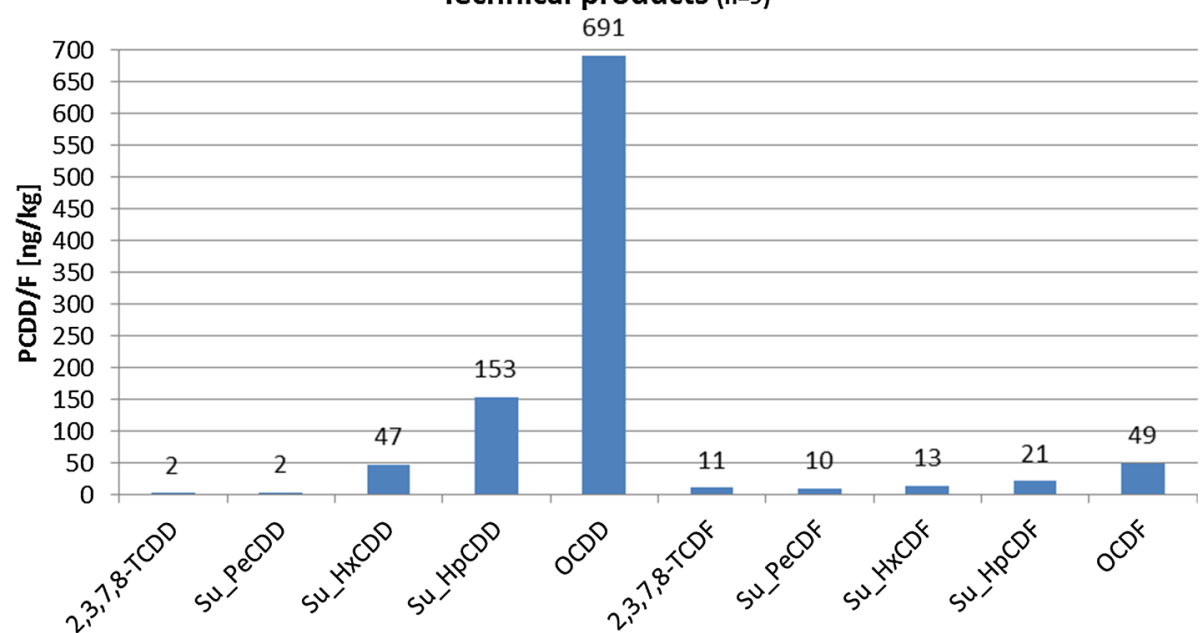

Fig. 9 Homologue pattern of technical products (UBA) (Data taken from [19])

that $\mathrm{PCDD} / \mathrm{F}$ values in soils of rural areas could strongly be determined by emissions related to technical products.

\section{Competing interests}

The author declares that he has no competing interests.

Ethics approval and consent to participate

Not applicable.

\section{Publisher's Note}

Springer Nature remains neutral with regard to jurisdictional claims in published maps and institutional affiliations.

Received: 3 July 2017 Accepted: 23 October 2017

Published online: 09 November 2017

\section{References}

\section{*Represents Unified Standards}

1. Fiedler H, Fricke K, Vogtmann H (1994) Bedeutung polychlorierter dibenzo-p-dioxine und dibenzofurane in der Abfallwirtschaft. Ecoinforma Press, Bayreuth

2. Marquardt H, Schäfer S (1994) Lehrbuch der Toxikologie. BI-Wiss.-Verl., Mannheim, p 1004

3. Hagenmaier HP, Krauss P, Wallenhorst T (1995) Einträge von Dioxinen in den Boden. In: DECHEMA e.V. [Hrsg.]: Kriterien zur Beurteilung organischer Bodenkontaminationen: dioxine (PCDD/F) und phtalate. Frankfurt am Main

4. van den Berg M, Birnbaum L, Bosveld ATC, Brunström B, Cook P, Feeley M, Giesy JP, Hanberg A, Hasegawa R, Kennedy SW, KubiakT, Larsen JC, van Leeuwen FXR, Liem AK, Nolt C, Peterson RE, Poellinger L, Safe S, Schrenk D, Tilitt D, Tysklind M, Younes M, Waern F, Zacharewski T (1998) Toxic equivalency factors (TEFs) for PCBs, PCDDs, PCDFs for humans and wild life. Environ Health Perspect 106:775-792

5. Bützer $P$ (2007) Temporal trends in human TCDD body burden: decreases over three decades and implications for exposure levels, Nature

6. Castro-Jiménez J, Deviller G, Ghiani M, Loos RG, Mariani G, Skejo H, Umlauf G, Wollgast J, Laugier T, Héas-Moisan K, Léauté F, Munschy C,
Tixier C, Tronczyński J (2008) PCDD/F and PCB multi-media ambient concentrations, congener patterns and occurrence in a Mediterranean coastal lagoon (Etang de Thau, France). Environ Pollut 156:123-135

7. Van den Berg M, Birnbaum LS, Denison M, De Vito M, Farland W, Feeley M, Fiedler H, Hakansson H, Hanberg A, Haws L, Rose M, Safe S, Schrenk D, Tohyama C, Tritscher A, Tuomisto J, Tysklind M, Walker N, Peterson RE (2006) The 2005 World Health Organizantion re-evaluation of human and mammalian toxic equivalency factors for Dioxin and Dioxin-like Compounds. Toxicol Sci 93(20:)221-241.

8. Boden AG (1994) Bodenkundliche Kartieranleitung, 4. Auflage, Hannover

9. LABO/LAGA/LAWA (1993) Einheitliche Bewertungsgrundsätze zu vorhandenen Bodenverunreinigungen/Altlasten. Bund-Länderarbeitsgemeinschaft Bodenschutz ( $L A B O)$, Länderarbeitsgemeinschaft Abfall (LAGA) und Länderarbeitsgemeinschaft Wasser (LAWA)

10. *DIN ISO 11465:12.96: Bodenbeschaffenheit - Bestimmung des Trockenrückstands und des Wassergehaltes auf Grundlage der Masse - Gravimetrisches Verfahren

11. *DIN 19683-2:04.97: Bodenuntersuchungsverfahren im Landwirtschaftlichen Wasserbau - Physikalische laboruntersuchungen, Bestimmung der Korngrößenzusammensetzung nach Vorbehandlung mit Natriumpyrophosphat

12. *DIN ISO 11464: Bodenbeschaffenheit, Probenvorbehandlung für physikalischchemische Untersuchungen

13. *DIN38414 - 24:04.98: Deutsche Einheitsverfahren zur Wasser-, Abwasserund Sedimentuntersuchungen -Schlamm und Sedimente (Gruppe S) - Teil 24: Bestimmung von polychlorierten Dibenzodioxinen (PCDD) und polychlorierten Dibenzofuranen (PCDF)

14. Reischl A, Zech W, Reissinger $M$, Lenoir $D$, Schramm K, Hutzinger $O$ (1990) Distribution of chlorinated aromatics in leaves, needles, and two soils from the fichtelgebirge (NE-Bavaria), FRG. Organohalogen Compd 4:223-238

15. Bayerisches Landesamt für Umwelt (2016) Hintergrundbelastung bayerischer Oberböden und Humusauflagen mit PCDD, PCDF und dIPCB

16. Joneck M, Hangen E, Wittenbecher M, Foullois N, Spörlein P, Martin M, Außendorf M, Reischl A (2006) Wissenschaftliche Grundlagen für den Vollzug der Bodenschutzgesetze in Bayern (GRABEN). Z.f. Bodenschutz 2:32-38

17. BMLFUW-UW (2008) Organische Schadstoffe in Grünlandböden—Report 0158, Umweltbundesamt Wien

18. UBA (2017) Dioxine und dioxinähnliche PCB in Umwelt und Nahrungsketten. Hintergrund, Umweltbundesamt

19. UBA (2016) Zuordnung und Quantifizierung der Dioxineinträge auf dem Luftpfad mittels Betrachtung der emissionsseitigen und immissionsseitigen Kongenerenmuster. Texte| 23/2016. Umweltbundesamt, Dessau-Rößlau 